\title{
Development and restoration of the urban rivers: examples from old downtown Tokyo, Japan
}

\author{
H. Gotoh ${ }^{1}$, M. Takezawa ${ }^{1}$, Y. Maeno ${ }^{1}$, H. Oshiki ${ }^{1}$, S. Nagashima ${ }^{2}$, \\ Y. Nishimura ${ }^{2} \&$ M. Ohta ${ }^{2}$ \\ ${ }^{1}$ Nihon University, Japan \\ ${ }^{2}$ Tokyo Metropolitan Government, Japan
}

\begin{abstract}
This paper describes the history of old downtown Tokyo and considers the extant flood control measures in the area. Old downtown Tokyo is surrounded by several rivers, and the area itself is serviced by numerous canals. Downtown Tokyo was originally constructed on the Tone River estuary in the 1600s after the route of the Tone River was changed by local inhabitations. The canals were originally used to transport supplies from the countryside to Edo (now Tokyo), seat of national government in the $17^{\text {th }}$ to $18^{\text {th }}$ centuries. When the main form of transport for such goods changed from boats to vehicles in the $19^{\text {th }}$ century, the unused canals were partially reclaimed. Old downtown Tokyo was a thriving commercial center before the $19^{\text {th }}$ century, but the area evolved into a factory district with the development of industry in 1900s. The considerable extraction of water for industrial use caused extensive land subsidence, which combined with the deforestation of the upper Tone River, resulted in old downtown Tokyo being susceptible to flooding since the mid $20^{\text {th }}$ century. Following extensive flood damage in the 1950s, old downtown Tokyo was restored and developed by the Tokyo Metropolitan Government (TMG) and the Ministry of Land, Infrastructure and Transport (MLIT) and large dikes were constructed along the Ara and Edo Rivers. Some of the canals in the old downtown areas of Tokyo were improved and restored by the TMG. Since the latter half of the $20^{\text {th }}$ century, numerous high-rise office and residential buildings have been constructed on reclaimed land and in the areas that were previously flooded. Based on the historical evidence of flooding in the area, it is important for local government to do the following: (1) promote the use of high-rise office and residential buildings
\end{abstract}


as shelters during flooding, (2) inform and educate inhabitants in high flood-risk areas of the dangers of flooding, (3) prepare supplies for flooding victims, and (4) construct structures that could be used by victims to secure themselves in the event they are swept away by floodwaters.

Keywords: flood hazard, old downtown Tokyo, river, canal, shelter, dike, floodgate.

\section{Introduction}

Numerous flooding disasters have occurred in throughout the world in recent years [1]. In Japan, flooding events are typically associated with typhoons and heavy downpours occur frequently throughout the country. Floods can occur during periods of abnormally heavy rainfall or when levees break. Previously, a typhoon caused extensive damage to the old downtown area of Tokyo, the capital city of Japan. However, subsequent river restoration and urban improvement projects have improved the area and the district is once again frequented by the citizens of Tokyo who come to the area for shopping and other forms of recreation. The period of postwar revival in the 1950s was characterized by frequent heavy rainfall events in the old downtown region of Tokyo, and the incidence of chest-deep floodwaters was frequent $[2,3]$.

However, the proposed construction of dikes and dams were proposed to reduce the threat of flooding in the area. Specially, the construction of a dam in the upper catchment, which would moderate the flow of runoff to the river reaches lower in the catchment, preventing floods, was proposed. But, despite the potential reduction in the occurrence of flooding due to the dam, the environmental impact and considerable required for such a project resulted in plans for the dam being put on hold. Consequently, an alternate plan involving reinforcement of existing dikes was proposed. Flood control measures of the time consisted primarily of dam construction or dike reinforcement, and both were extensively employed in the subsequent urban improvement projects undertaken in the lower regions of the catchment area. However, the impact on the natural environment has been considerable.

Over the last 100 years, numerous large-scale artificial improvements have been undertaken in the rivers in Japan. Taken together, these developments have had a marked impact ecosystem functioning and scenery of these systems. Consequently, a method for managing floods, consisting of effective land policy without the need for a dam was, was undertaken. On a premise of river overflowing, the flooding area has to be set in the place that a person has already lived a life not what only the river improvement such as a dam and a dike. Given that it is not possible to completely prevent flooding, the development of a citizen-based town planning initiative for surviving a flooding disaster is important. Such an approach would effectively harness the collective wisdom of the inhabitants of an area and help them to minimize the potential for damage to both property and personal safety. 


\section{Old downtown Tokyo}

The city that is now Tokyo was originally a small fishing village named Edo. In 1590, Tokugawa Ieyasu designated Edo as his base and when he became shogun in 1603 and the town became the center of his national military government. During the subsequent Edo period, Edo developed into one of the largest cities in the world with a population exceeding one million by the $18^{\text {th }}$ century.

Tokyo is situated northwest of Tokyo Bay, and extends approximately $90 \mathrm{~km}$ from the east to the west and $25 \mathrm{~km}$ from the north to the south (Figure 1). The city is further subdivided into special wards and the Tama area stretching westwards. Also falling within the administrative boundaries of TMG are two island chains directly to the south in the Pacific Ocean: the Izu Islands, and the Ogasawara Islands, which stretch more than $1,000 \mathrm{~km}$ away from mainland Japan. The city contains 23 special wards, which until 1943 were all administered centrally by the city of Tokyo; each is now a separate, selfgoverning municipality, each with a mayor and a council, and having the status of a city. Tokyo also has an additional 26 more cities, five towns and eight villages [4].

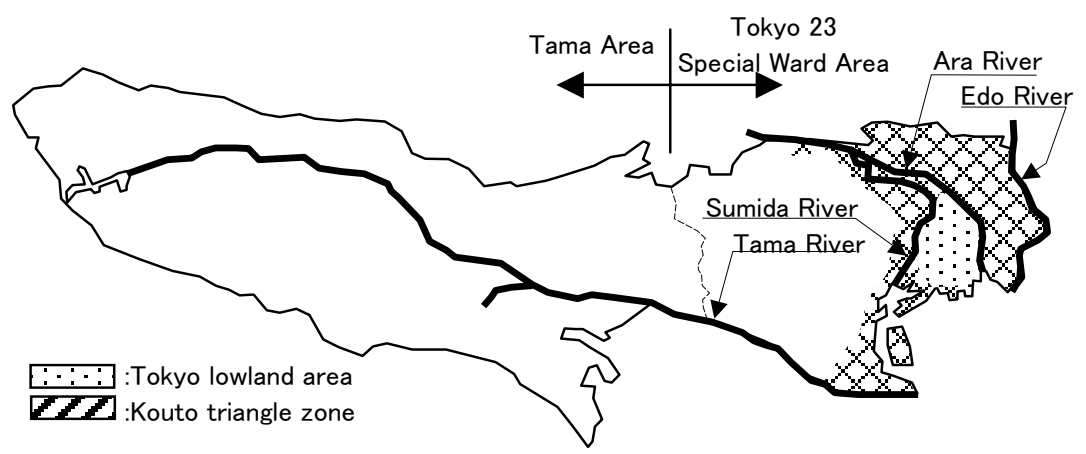

Figure 1: Geophysical map of Tokyo.

Topographically, TMG has mountainous areas to the west, hills and a plateau in the center, and lowlands to the east. The old downtown area is situated in a physically low-lying area on an alluvial bed consisting of a thick layer of soft earth and sand, which was previously a delta formed by the Tone and Ara river. Over time, numerous physical changes have been made to rivers in the delta, primarily for irrigation, but later in the early days of Tokugawa shogunate government, for waterway and transport, and an inning of damp ground in the Tone and Ara rivers. Subsequently, for reasons related to flood control, the Ara River drain canal was excavated by taking a chance in response to deluges in 1907 and 1910, and the Naka River drain canal was constructed after a flood in 1938 (Figure 2). 


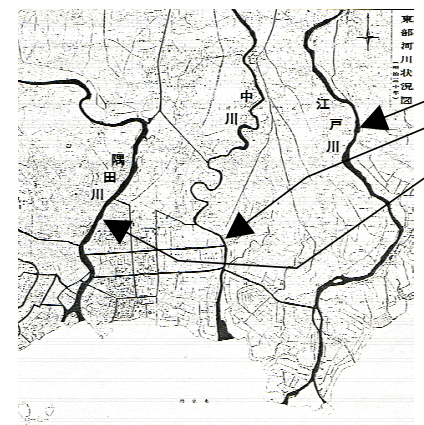

(a) Meiji Era

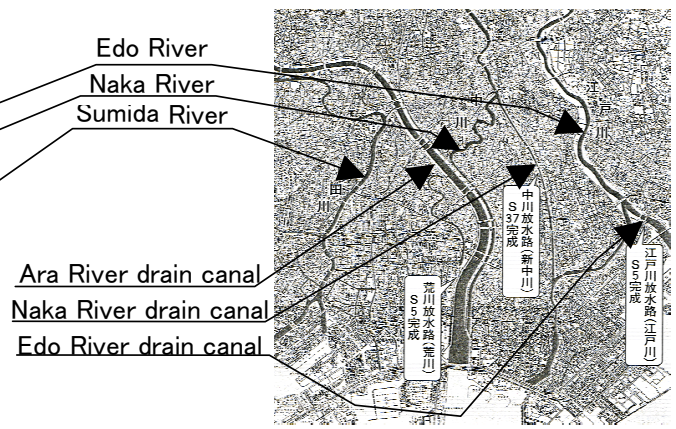

(b) Present day

Figure 2: $\quad$ Changes in the lowland rivers of downtown Tokyo over time [5].

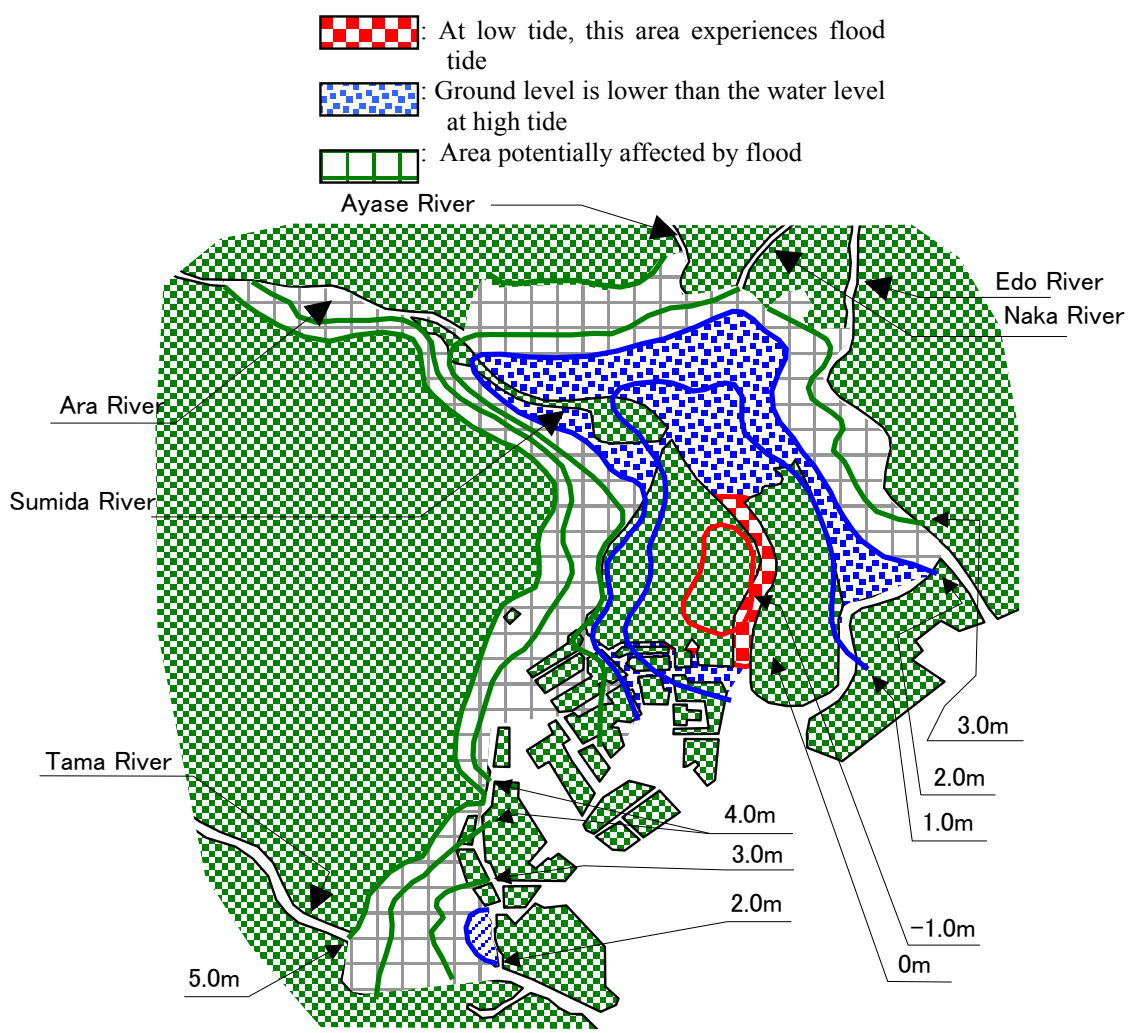

Figure 3: Ground levels (meters above sea level) in the lowland area of downtown Tokyo [6]. 
In this way, the lowlands of old downtown Tokyo were changed from being marshland to markets. However, in the $20^{\text {th }}$ century, old downtown Tokyo was developed as an industrial area, and this was associated with widespread subsidence of the land in the area due to the extraction of groundwater for industrial use. To prevent further land subsidence, the extraction of water for industrial use was regulated in 1961, when the use of groundwater was regulated by the law. Consequently, a marked decrease in the subsidence of lowland occurred and ground levels in the area have currently ceased in the region. Figure 3 shows the grand level of the lowland areas in old downtown Tokyo in the Meiji Era and today $[5,6]$.

\section{Development of river works in the lowlands of the old downtown area}

Before the Second World War, the Ara, Edo and Naka rivers that flowed through the lowland of the Tokyo downtown area were developed for transport and stormwater drainage.

In 1910, heavy and prolonged rainfall in the Kanto region caused the Ara River to overflow, causing inundation of an area spanning $201.43 \mathrm{~km}^{2}$, damage to 178,000 flooded houses, 169 casualties, and 245 missing people, the rupture of dikes in 300 places, and 200 instances of bridge damage in Tokyo. The event prompted the government to construct the Ara River flood control channel in 1911, which was completed in 1930. In 1917, the old downtown areas of Tokyo were damaged by high tide event, which caused $86.6 \mathrm{~km}^{2}$ to be inundated, 180,000 houses to be flooded, and 1524 casualties in Tokyo.

Similarly, flooding in eastern Tokyo in 1938 prompted the government to develop the Naka flood control channel along the Edo River. Although these plans were halted by the Second World War, work on the Naka flood control channel was resumed in 1949, because the lowland areas of downtown Tokyo was severely damaged by typhoons Kathleen (1947), Ion (1948) and Kitty (1949) as shown in Table 1. Soon after Kathleen struck, the dikes of the Edo River broke, flooding an area of $114.33 \mathrm{~km}^{2}$ containing, 125,000 houses and causing 11 fatalities. Typhoon Kitty struck during high tide in Tokyo Bay, causing an abnormally high increase in sea level which flooded an area exceeding $92.01 \mathrm{~km}^{2}$ containing approximately 140,000 houses. Approximately 2800 boats were destroyed and 122 people died. Table 1 shows the main episodes of flood damage in Tokyo since 1910.

After the Second World War, the population of Japan increased rapidly and the areas surrounding the lower river reaches became urbanized. The extensive damage to the country's infrastructure and relative neglect of flood mitigation measures due to the long war, meant that flood damage at this time was particularly severe. In addition, the extensive and sudden urban development on the alluvial plain meant that any direct hit by a large typhoon and extended periods of rainfall would likely cause extensive damage. Consequently, in 1948, the Ministry of Construction (MLIT) started implementing flood mitigation measures in the Tokyo downtown area. Dams were constructed in a river basin 
of the Tone River for ameliorate the typhoon-damage, such as the widespread damage that occurred when typhoon Kathleen struck in 1947. The Japanese Government also implemented policies directed at reducing flood damage by establishing a flood control organization in 1947, and promulgated the Flood Control Law in 1949. Furthermore, in response to the extensive damage caused by Typhoon Kitty in 1949, the Japanese Government and TMG implemented a variety of anti-high tide measures, including dikes, seawalls, tide gates, etc. In 1958, Typhoon Kanogawa caused marked damage to the low-lying areas of old downtown Tokyo, flooding an area of $211.03 \mathrm{~km}^{2}$, including 463,000 houses and causing 203 casualties. The introduction of protective measures for river and harbor areas, such as tide barriers, revetments, water gates was initiated in 1957 and finished in 1966. The combined effect of these measures meant that flood damage decreased since 1967 in old downtown Tokyo. For example, despite the Tone River flooding in 1981 and 1982, old downtown Tokyo was not damaged. Regarding the anti-high tide measures that have been implemented by TMG,

Table 1: $\quad$ Records of the main flood damage in Tokyo [5].

\begin{tabular}{|c|c|c|c|c|c|}
\hline Year & Disaster & $\begin{array}{c}\text { Flooded } \\
\text { area } \\
\left(\mathrm{km}^{2}\right)\end{array}$ & $\begin{array}{c}\text { Flood } \\
\text { to floorboard } \\
\text { level(houses) }\end{array}$ & $\begin{array}{c}\text { Flood above } \\
\text { floorboard } \\
\text { level(houses) }\end{array}$ & $\begin{array}{c}\text { Casualties } \\
\text { (people) }\end{array}$ \\
\hline 1910 & storm (flooding) & 201.43 & 133,307 & 44,750 & 169 \\
\hline 1917 & storm(high tide) & 86.60 & 131,334 & 49,004 & 1,524 \\
\hline 1938 & storm (high tide) & 77.90 & 42,867 & 65,703 & 38 \\
\hline 1947 & Typhoon (flooding) & 114.33 & 80,041 & 45,167 & 11 \\
\hline 1948 & Typhoon (flooding) & 28.64 & 529 & 16,516 & 24 \\
\hline 1949 & Typhoon (high tide) & 92.01 & 73,751 & 64,127 & 122 \\
\hline 1958 & Typhoon (high tide) & 29.46 & 13,459 & 22,970 & 133 \\
\hline 1958 & Typhoon (flooding) & 211.03 & 123,626 & 340,404 & 203 \\
\hline 1966 & Typhoon (flooding) & 87.62 & 16,159 & 86,737 & 9 \\
\hline 1979 & Typhoon (high tide) & 1.46 & 180 & 1,550 & 99 \\
\hline 1981 & Typhoon (flooding) & 19.59 & 6,854 & 35,167 & 4 \\
\hline 1982 & Typhoon (flooding) & 16.16 & 7,574 & 16,712 & 0 \\
\hline 1989 & Heavy rain(flood) & 0.82 & 1,929 & 2,755 & 0 \\
\hline 1991 & Typhoon (flooding) & 1.78 & 561 & 3,120 & 1 \\
\hline 1993 & Typhoon (flooding) & 3.42 & 2,454 & 5,079 & 0 \\
\hline 1999 & Heavy rain(flood) & 1.54 & 2,900 & 2,193 & 0 \\
\hline 2005 & Heavy rain(flood) & 1.72 & 3,374 & 2,453 & 0 \\
\hline
\end{tabular}




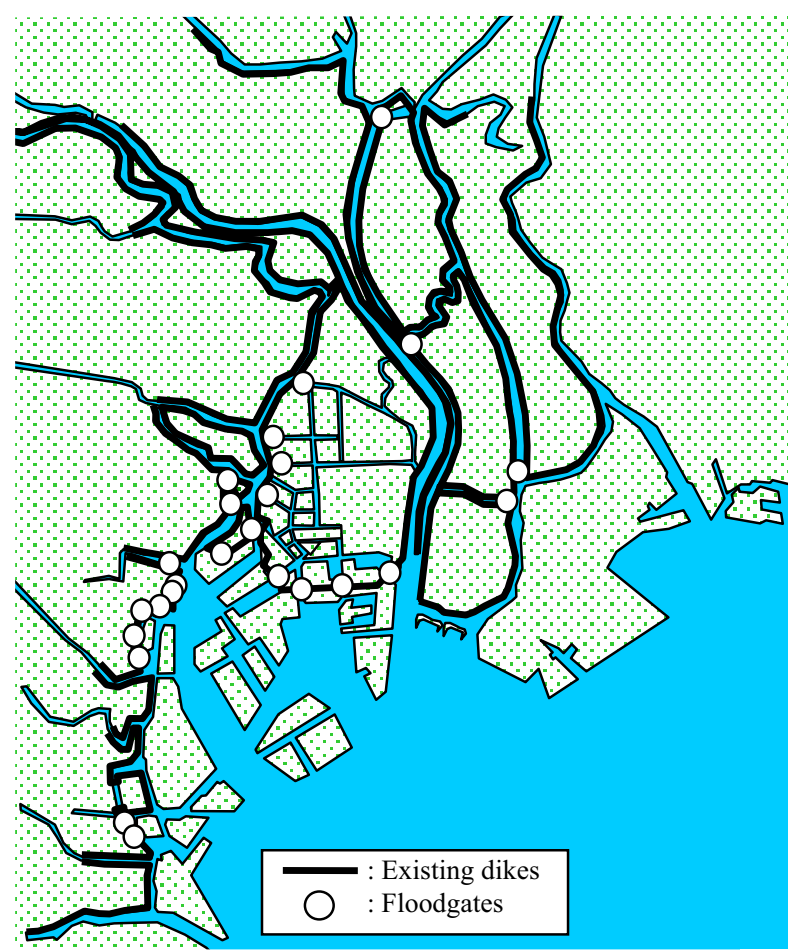

Figure 4: High tide defense measures in old downtown Tokyo [5-7].

about $95 \%$ of the measures, including tide barriers, revetments and water gates were completed by March 2007 [5-7] (Figure 4). However, despite the reduction in floods and gradual improvement in water quality, the extensive use of concrete revetments has meant that local inhabitants do not feel the sense of community toward the river.

Gentle slope-type dikes that are relatively resilient to large earthquakes and which contribute to the local environment have been built at the Sumida River since 1980 (Figure 5). However, the use of super dikes, which are wide earthen dikes have been used as flood and earthquake damage mitigation measures on the land adjacent to rivers since 1985, has meant that these areas are considered to contribute positively toward the river and city environments (Figure 6).

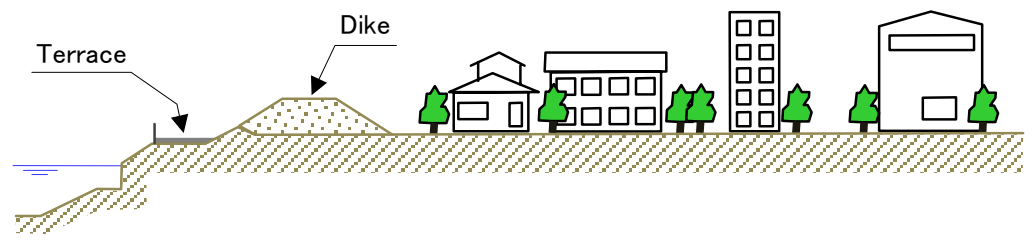

Figure 5: A gentle slope-type dike [5]. 


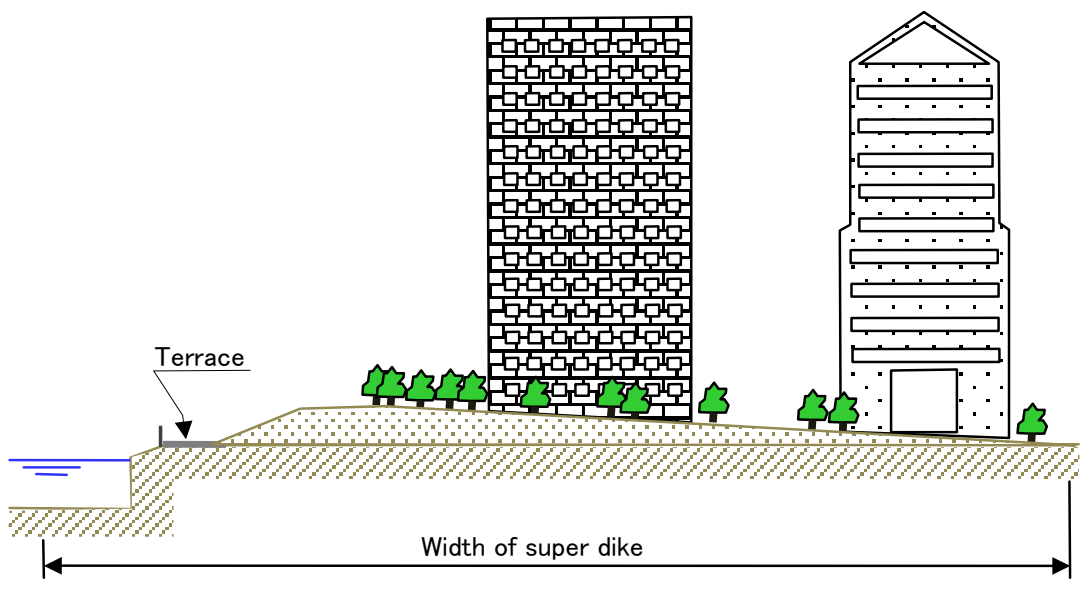

Figure 6: A super dike.

Furthermore, the maintenance of terraces for the purpose of waterside use and quake resistance of super dikes has been undertaken since 1987. Since 1995, the ability of river structures such as dikes, water gates, drainage pumps, etc. to withstand earthquakes has been checked, and earthquake-proofing measures have been undertaken in those structures in which such structural strength is considered insufficient. In addition, procedures have either been planned or performed to facilitate the removal of illegally parked boats that obstruct river courses, construct mooring facilities, transfer people in times of disaster, provide temporary mooring of small boats, etc.

\section{Canal's maintenance of old downtown Tokyo}

Of the 23 special wards in TMG, four (Koto, Edogawa, Sumida and Katsushika) are located between the Sumida and Edo rivers. Canals of the Koto special ward served as an important role model for the development of both Edo/Tokyo and old downtown Tokyo. These canals have long been associated with the people living in their vicinity. However, the close relationship that exists between people, canals and their neighborhood has been disrupted by the industrialization, floods, and water pollution that characterized the area in the 1950s.

Since 1971, maintenance of the canals in Koto special ward have been carried out by TMG, which has attempted to restore the connection between the people and their environment. Figure 7 shows an outline of the canals maintenance that has been conducted in the Koto district of downtown Tokyo. It is hoped that these efforts, combined with those of local inhabitants, will result in an improvement of the canals in Koto special ward, particularly in the areas of flood control and water pollution. Such citizen-based town planning will ensure the provision of valuable surface of water, takes in water and green areas in a large 
city, increasing the comfort of the local inhabitants and visitors. The canals that flow through Koto special ward facing the coastal zone link the much larger Ara and Sumida rivers. Other areas in old downtown Tokyo with canals have been restored through the concerted efforts of inhabitants and the local municipalities. Furthermore, such improvements in old downtown Tokyo will be promoted by going ahead networks of water and green, recreation, history and culture or disaster prevention [8].

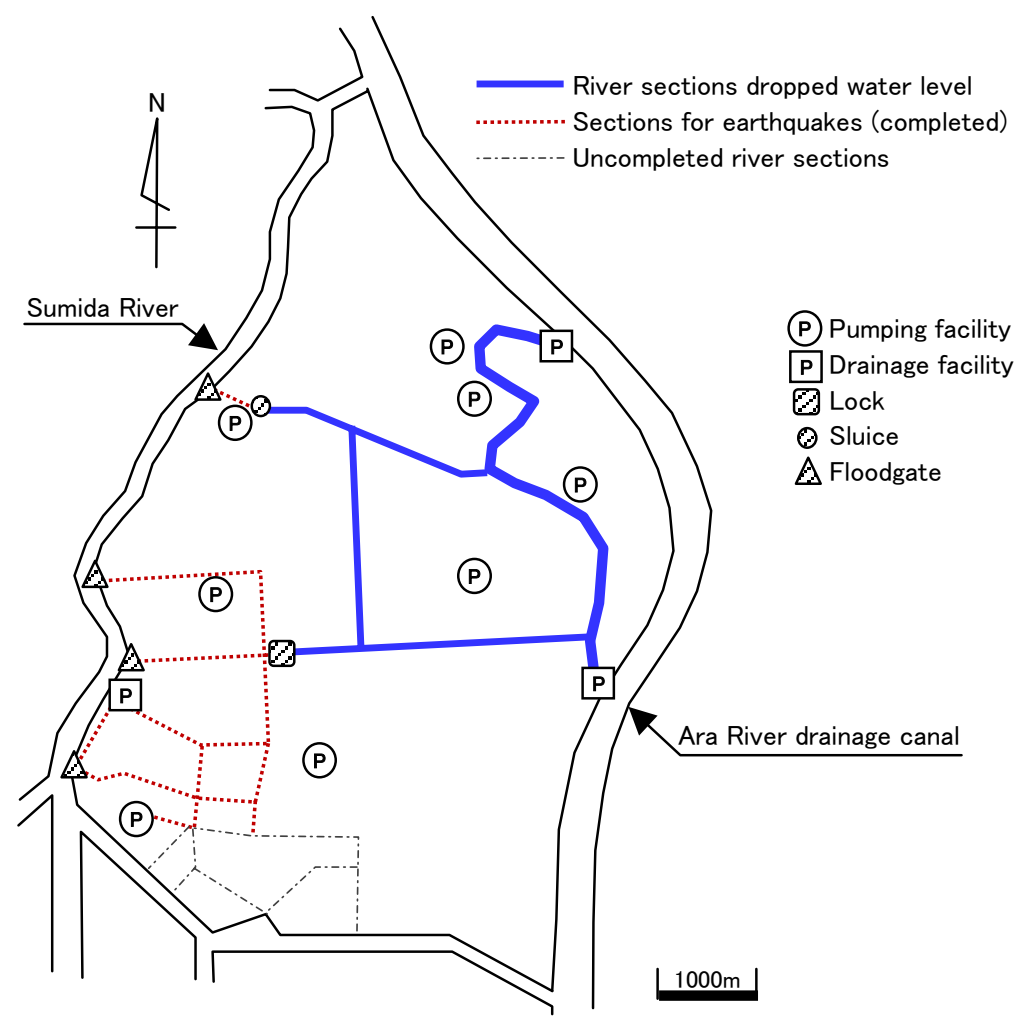

Figure 7: $\quad$ Map of maintenance to canals [5].

\section{Measures of before-during-after a flood}

Efficient collection, dissemination, and sharing of information between administration officials and citizens are extremely important at the time of a disaster. A system of river administration for protecting low-lying areas of old downtown Tokyo has been advanced by the MLIT and TMG. With the cooperation of citizens, the media, companies, administrative officials and bodies, an information network of the river basin will be created for use during both non-emergencies and emergencies. Such systems will include information such as water levels and precipitation on Community Antenna Television 
(CATV) and on the internet. The systems will show the nearest police stations, hospitals, emergency collection points, etc. In addition, citizens will be able to construct their own maps in preparation for times of disaster, such as meeting points for family and the friends in the event that they became separated. Moreover, recreation activities and lifestyle information will be transmitted on CATV. In the event of a disaster, access to affected communities by emergency workers is often problematic, particularly if roads become seriously damaged. However, in the downtown area of Tokyo, in the event of a disaster these waterways could serve as conduits for people, services and supplies.

An emergency chartered boat mooring will be used for loading and unloading the material and machine parts that are necessary for restoration activities during disaster. In addition, disaster prevention stations need to be established from which it will be possible to coordinate rescue efforts and to store the various materials and equipment required for flood control activities. In the others, a method for controlling river traffic and disseminating navigation information needs to be developed for transporting supplies during disasters. In addition to the maintenance of such an information and transportation network, regular inspections and checks of dikes and water gates need to be performed daily. In addition, it is essential that inhabitants have a thorough understanding of what to do in the event of an emergency and that they are highly familiar with all of the aspects of the emergency response in their neighborhood. Particularly, all residents should have illustrated hazard maps showing the extent of inundation, refuge sites, a refuge route that they will follow based on previous flooding simulations. In doing so, inhabitants will be able to seek refuge quickly and at smoothly in the event of an emergency.

In old downtown Tokyo, which has numerous subways and underground shopping centers, the communication system and required response required for communicating emergency information must be known to everybody and establish improvement of sense of impending crisis and a disaster prevention body system. While emergency procedures are often well communicated and planned in organizations and offices, similar emergences at the level of the family are poorly thought out [9]. The Cabinet Office of Japanese Government gathered information on measures of flood hazards through a questionnaire for 334 municipalities on the outskirt of Tokyo in 2008. Main results are as follows: (1) It is about $52 \%$ of municipalities to recognize that there is a danger of inundation at central government office building, and it is about $40 \%$ of them to appoint a substitute institution establishing anti-disaster headquarter, (2) About $29 \%$ of municipalities including an inundation assumption area of the Tone and Ara rivers do not have a clear standard of evacuation advisory, (3) Municipalities which fix objective numerical values for a criterion of evacuation advisory are about $22 \%$, (4) About $17 \%$ of municipalities including an inundation assumption area of the Tone and Ara rivers do not keep a refuge with a danger of inundation under flood control, (5) Among municipalities keeping a refuge with a danger of inundation under flood control, it is about $44 \%$ to distinguish a refuge for earthquakes and floods, (6) When a refuge was flooded, it is about 53\% to use upper stories which are not flooded, (7) About 54\% of municipalities assuming 
the situation that a refuge is necessary do not have a refuge plan to other municipalities, (8) Among municipalities with a refuge plan of wide area, there are not municipalities preparing the manual which mentioned means of a concrete guidance of the wide area refuge, (9) Municipalities getting the guide system which cooperated with the police and other institutions as a guidance of a wide area refuge are about $73 \%$, (10) Municipalities assuming the refuge to upper stories of business buildings and apartment houses are about $23 \%$, and about $3 \%$ of them conclude an agreement with managers of buildings and houses about handling sufferers of outdoors [10].

The Federal Emergency Management Agency of the U.S. government defines activities that need to be undertaken before, during and after a flood event [11]; a similar procedure needs to be defined for the Japanese situation.

\section{Conclusions}

There is a proverb in Japan that "disasters are overcome when we forgot about it". There is no evidence of the disasters that once destroyed the old downtown area. The area is dominated now by high-rise buildings and large stores where young people gather. The population of the area is increasing at a time when that of nearby cities is decreasing. Interestingly, many of the current younger generation do not know that old downtown Tokyo was totally destroyed by a typhoon in 1950s, and the lessons and experiences of the older generation are being forgotten. This is because scientific progress has resolved many of the problems associated with rivers overflowing their banks, sewage spills, and extensive flooding. It is therefore necessary to designate a hill as an emergency gathering point that is known to all inhabitants in the event that there is a flood. In addition, the foundations of buildings need to be raised in areas where there is a risk of flooding, embankments and bulkheads need to be placed around buildings, and trees need to be planted around houses. It is very important for us to explore these and other methods for protecting ourselves in the event of flooding. We need to ask ourselves questions like: what can we do before, during and after a flood? Old downtown Tokyo has played a significant role for a living of a town.

The city Edo has been regenerated. The dikes and restored rivers and canals in old downtown Tokyo have been bulked in height and widened, and their earthquake proofing and reinforcement have been conducted for many years. Water pollution of the rivers and canals has been improved and old downtown Tokyo has been reborn as a place of recreation and relaxation for metropolitan citizens. In future, straightforward preventative measures in response to flood hazards need to be developed for local inhabitants near canals and along the coastal zone. In the event of a flood in old downtown Tokyo, high-rise offices and residential buildings will need to be used as shelter and the cooperation of inhabitants, companies, and organization needs to be sought. Local governments and administrative bodies need to inform and educate their inhabitants to be responsible in the face of such disasters. In addition, considerable amounts of supplies for flooding victims need to be prepared by local governments and 
refuges need to be constructed in dangerous places. The population density of old downtown Tokyo is very high $\left(10,000-20,000\right.$ persons $\left./ \mathrm{km}^{2}\right)$ and numerous visitors and go to the big shopping centers and amusement parks in the area. While it is important to consider flood control measures, it is important not to forget about relief measures.

\section{References}

[1] Kron, W., Dealing with Flood Risk, Stockholm Waterfront, No.3, pp.16, 2006.

[2] Takahashi, Y., CATHERINE: A TYPHOON'S-EYE VIEW, Caught flatfooted: multiple catastrophes overcome by human resourcefulness, A Magazine on Rivers, No.12, pp.3 14, 1998.

[3] Kugihara, N., MOB PANIC! In a disaster like Typhoon Catherine, A Magazine on Rivers, No.12, pp.18 21, 1998

[4] Tokyo Metropolitan Government, Overview of Tokyo, http://www.metro.tokyo.jp/ENGLISH/PROFILE/overview01htm, 2009

[5] Bureau of Construction, Tokyo Metropolitan Government, River works of lowland in Tokyo, 2007.

[6] Division of River, Bureau of Construction, Tokyo Metropolitan Government, River Works of lowland in Tokyo, http://www.kensetsu.metro.tokyo.jp, 2009.

[7] Bureau of Port \& Harbor, Tokyo Metropolitan Government, Disaster Prevention Project of Tokyo Port, 2008.

[8] Aoshima, Y., Report of the meeting for creating the future rivers in downtown Tokyo, Tokyo Metropolitan Government, pp.65 66, 1998.

[9] http://www.ara.go.jp/arage/outline/03-4.html, The lower reaches office of the Ara River, Ministry of Land, Infrastructure and Transport, 2009

[10] Cabinet Office of Japanese Government, Questionnaire on measures of flood control measures on a large scale, Central Disaster Meeting in Japanese Government, http://www.bousai.go.jp/chubou/chubou.html, 2009

[11] FEMA, Flood, http://www.fema.gov/hazard/flood/index.shtm, 2009 